\title{
Parental Educational Level As A Predictor Towards The Return Rate Of Pre-Primary and Primary Pupils To School Amidst Coronavirus Pandemic in Port Harcourt Metropolis, Nigeria
}

\author{
Dr. Anero, Nnamdi \\ Department of Early Childhood and Primary Education, \\ Faculty of education, ignatius Ajuru University of Education \\ Port Harcourt, Nigeria. \\ Okankwu, Elizabeth Amini \\ Department of Nursing Sciences \\ Faculty of Clinical Sciences, College of Medical Sciences \\ Rivers State University Port Harcourt, Nigeria
}

\begin{abstract}
The study was carried out to determine the extent parental educational levels predict return rate of pre-primary and primary pupils by parents as soon as the schools resume at the end or close to the end of coronavirus pandemic. The study which was carried in Port Harcourt, Nigeria adopted accidental sampling technique to sample 942 parents out of a population of 476,658 parents. Four research questions guided the study. The major instrument for the study was the Researchers made questionnaire titled "Return of children to school by parents amidst coronavirus pandemic". The data generated was analyzed using simple percentage. Findings showed that parents whose educational levels were within non-completion of primary school education and Diploma certificates will return their children on the ground that schools can effectively administer hand washing by pupils while those with first degrees to the terminal degrees disagreed with the ability of schools to carry out a hand wash exercise. However, the parents generally agreed that the schools cannot maintain the required social distancing and administer frequent fluid intake to pupils as preventive measures and as a result would not return their children to schools. Based on these findings, the study among other things recommended thus: since some category of parents agree that the schools cannot enforce hand wash by children, NGO'S and public spirited individuals need to enlighten the schools on the need to take the business of hand wash serious; since the schools cannot maintain adequate spacing, the government and her agencies must urge the schools to operate two to three shifts so as to have adequate space and facilities that would enable them maintain the recommended social or physical distancing and that any school that will operate, must have a source of portable water confirmed by National Agency for Food and Drug Administration and Control (NAFDAC).
\end{abstract}


Anero, N., \& Okankwu, E. A. (2020). Parental Educational Level as a Predictor Towards the Return Rate of Pre-Primary and Primary Pupils to School Amidst Coronavirus Pandemic in Port Harcourt Metropolis, Nigeria. Advances in Social Sciences Research Journal, 7(5) 157-172.

\section{INTRODUCTION}

Contemporarily, coronavirus infection is the most devastating calamity on earth that has attracted the attention of all and sundry from all works of life. The disease was first reported at the verge of 2019, at Hunan market in Wuhan, China where sea foods and animals such as rabbits, frogs, snakes, marmots, birds and bats are sold. Initial manifestation was mistaken and managed as pneumonia and by the time the World Health Organization (WHO) was notified, a total of 44 persons were already affected by the virus (WHO, 2020). Medical observation shows that coronavirus symptomatically manifest as fever, cough, sore throat, headache, muscle pain, shortness of breath. Others symptoms are delirium, hemoptysis, kidney failure among other.

Descriptively, David (2020) described it as an illness caused by novel coronavirus now called severe acute respiratory syndrome coronavirus 2 (SARS-COV- 2). In a related understanding, WHO (2020) described coronavirus as an infectious disease caused by a newly discovered coronavirus. Going by these views, one can infer that coronavirus is a severe acute respiratory viral infection of the family of coronaviruses. Considering its novelty nature and the unprepared posture of the entire world medical practitioners, one may not be faulted to think that it has affected almost all parts of the globe. Its occurrence in terms of date and number of persons affected in different countries are as shown in Table 1.The table shows names of countries, date of first incidence of infection and number of victims.

Table 1.Names of countries, date of first incidence of infection and number of victims.

\begin{tabular}{|c|c|c|c|}
\hline SN & Name of country & $\begin{array}{l}\text { Date of } 1 \text { st incidence of } \\
\text { infection }\end{array}$ & Number of cases \\
\hline \multicolumn{4}{|c|}{ AFRICAN CONTINENT } \\
\hline 1 & ALGERIA & $25 / 2 / 2020$ & 1 \\
\hline 2 & ANGOLA & $21 / 3 / 2020$ & 2 \\
\hline 3 & BENIN & $16 / 3 / 2020$ & 1 \\
\hline 4 & BOTSWANA & $30 / 3 / 2020$ & 3 \\
\hline 5 & BURKINA FASO & $9 / 3 / 2020$ & 2 \\
\hline 6 & BURUNDI & $31 / 3 / 2020$ & 2 \\
\hline 7 & CAMEROON & $6 / 3 / 2020$ & 1 \\
\hline 8 & CAPE VERDE & $26 / 3 / 2020$ & 1 \\
\hline 9 & CENTRAL AFRICAN REPUBLIC & $14 / 3 / 2020$ & 1 \\
\hline 10 & CHAD & $19 / 3 / 2020$ & 1 \\
\hline 11 & CONGO-BRAZZAVILLE & $10 / 32020$ & 1 \\
\hline 12 & DR CONGO & $14 / 3 / 2020$ & 1 \\
\hline 13 & DJIBOUT & $18 / 3 / 2020$ & 1 \\
\hline 14 & EGYPT & $14 / 2 / 2020$ & 1 \\
\hline 15 & EQUATORIAL GUINEA & $14 / 3 / 2020$ & 1 \\
\hline 16 & ERITREA & $20 / 3 / 2020$ & 1 \\
\hline 17 & ESWATINI & $14 / 3 / 2020$ & 1 \\
\hline 18 & ETHIOPIA & $13 / 3 / 2020$ & 1 \\
\hline 19 & GABON & $12 / 3 / 2020$ & 1 \\
\hline 20 & THE) GAMBIA & $17 / 3 / 2020$ & 1 \\
\hline 21 & GHANA & $12 / 3 / 2020$ & 2 \\
\hline 22 & GUINEA & $13 / 3 / 2020$ & 1 \\
\hline 23 & GUINEA-BISSAU & $25 / 3 / 2020$ & 2 \\
\hline 24 & IVORY COAST & $11 / 3 / 2020$ & 1 \\
\hline 25 & KENYA & $12 / 3 / 2020$ & 1 \\
\hline 26 & LIBERIA & $16 / 3 / 2020$ & 1 \\
\hline 27 & LIBYA & $23 / 3 / 2020$ & 1 \\
\hline 28 & MADAGASCAR & $20 / 3 / 2020$ & 3 \\
\hline
\end{tabular}


Advances in Social Sciences Research Journal (ASSRJ)

Vol.7, Issue 5, Apr-2020

\begin{tabular}{|c|c|c|c|}
\hline 29 & MALAWI & $2 / 4 / 2020$ & 3 \\
\hline 40 & MALI & $25 / 3 / 2020$ & 2 \\
\hline 31 & MAURITANIA & $13 / 3 / 2020$ & 1 \\
\hline 32 & MAURITIUS & $19 / 3 / 2020$ & 3 \\
\hline 33 & MOROCCO & $2 / 32020$ & 1 \\
\hline 34 & MOZAMBIQUE & $22 / 3 / 2020$ & 1 \\
\hline 35 & NAMIBIA & $14 / 3 / 2020$ & 2 \\
\hline 36 & NIGER & $19 / 3 / 2020$ & 1 \\
\hline 37 & NIGERIA & $27 / 2 / 2020$ & 1 \\
\hline 38 & RWANDA & $14 / 3 / 2020$ & 1 \\
\hline 39 & SAO TOME AND PRINCIPE & $16 / 3 / 2020$ & 4 \\
\hline 40 & SENEGAL & $2 / 3 / 2020$ & 1 \\
\hline 41 & SEYCHELLES & $14 / 3 / 2020$ & 2 \\
\hline 42 & SIERRA LEONE & $31 / 3 / 2020$ & 1 \\
\hline 43 & SOMALIA & $16 / 3 / 2020$ & 1 \\
\hline 44 & SOUTH AFRICA & $5 / 3 / 2020$ & 1 \\
\hline 45 & SOUTH SUDAN & $5 / 4 / 2020$ & 1 \\
\hline 46 & SUDAN & $13 / 3 / 2020$ & 1 \\
\hline 47 & TANZANIA & $16 / 3 / 2020$ & 1 \\
\hline 48 & TOGO & $16 / 3 / 2020$ & 1 \\
\hline 49 & TUNISIA & $2 / 3 / 2020$ & 1 \\
\hline 50 & UGANDA & $20 / 3 / 2020$ & 1 \\
\hline 51 & ZAMBIA & $18 / 3 / 2020$ & 2 \\
\hline 52 & ZIMBABWE & $15 / 3 / 2020$ & 1 \\
\hline \multicolumn{4}{|c|}{ ASIAN CONTINENT } \\
\hline 53 & AFGHANISTAN & $24 / 2 / 2020$ & 1 \\
\hline 54 & ARMENIA & $29 / 2 / 2020$ & 1 \\
\hline 55 & AZERBAIJAN & $28 / 2 / 2020$ & 1 \\
\hline 56 & BAHRAIN & $21 / 2 / 2020$ & 1 \\
\hline 57 & BANGLADESH & $7 / 3 / 2020$ & 3 \\
\hline 58 & BHUTAN & $6 / 3 / 2020$ & 1 \\
\hline 59 & BRUNEI & $9 / 3 / 2020$ & 1 \\
\hline 60 & CAMBODIA & $27 / 1 / 2020$ & 1 \\
\hline 61 & CHINA & $1 / 12 / 19$ & 1 \\
\hline 62 & CYPRUS & $9 / 3 / 2020$ & 2 \\
\hline 63 & EAST TIMOR & $20 / 3 / 202$ & 1 \\
\hline 64 & GEORGIA & $26 / 2 / 2020$ & 1 \\
\hline 65 & HONG KONG & $23 / 1 / 2020$ & 1 \\
\hline 66 & INDIA & $30 / 1 / 2020$ & 1 \\
\hline 67 & INDONESIA & $2 / 3 / 2020$ & 2 \\
\hline 68 & IRAN & $19 / 2 / 2020$ & 2 \\
\hline 69 & IRAQ & $22 / 2 / 2020$ & 1 \\
\hline 70 & ISRAEL & $21 / 2 / 2020$ & 1 \\
\hline 71 & JAPAN & $6 / 3 / 2020$ & 1 \\
\hline 72 & KAZAKHSTAN & $13 / 3 / 2020$ & 2 \\
\hline 73 & KUWAIT & $24 / 2 / 2020$ & 1 \\
\hline 74 & KYRGYZSTAN & $18 / 3 / 2020$ & 3 \\
\hline 75 & LAOS & $24 / 3 / 2020$ & 2 \\
\hline 76 & LEBANON & $21 / 2 / 2020$ & 1 \\
\hline 77 & MACAU & $22 / 1 / 2020$ & 1 \\
\hline
\end{tabular}


Anero, N., \& Okankwu, E. A. (2020). Parental Educational Level as a Predictor Towards the Return Rate of Pre-Primary and Primary Pupils to School Amidst Coronavirus Pandemic in Port Harcourt Metropolis, Nigeria. Advances in Social Sciences Research Journal, 7(5) 157-172.

\begin{tabular}{|c|c|c|c|}
\hline 78 & MALAYSIA & $25 / 1 / 2020$ & 3 \\
\hline 79 & MALDIVES & $7 / 3 / 2020$ & 2 \\
\hline 80 & MONGOLIA & $10 / 3 / 2020$ & 1 \\
\hline 81 & MYANMAR & $23 / 3 / 2020$ & 2 \\
\hline 82 & NEPAL & $24 / 1 / 2020$ & 1 \\
\hline 83 & OMAN & $24 / 2 / 2020$ & 2 \\
\hline 84 & PAKISTAN & $26 / 2 / 2020$ & 1 \\
\hline 85 & PALESTINE & $5 / 3 / 2020$ & 7 \\
\hline 86 & PHILIPPINES & $30 / 1 / 2020$ & 1 \\
\hline 87 & QATAR & $29 / 2 / 2020$ & 1 \\
\hline 88 & RUSSIA & $31 / 1 / 2020$ & 2 \\
\hline 89 & SAUDI ARABIA & $2 / 3 / 2020$ & 1 \\
\hline 90 & SINGAPORE & $23 / 1 / 2020$ & 1 \\
\hline 91 & SRI LANKA & $27 / 1 / 2020$ & 1 \\
\hline 92 & SYRIA & $22 / 3 / 2020$ & 1 \\
\hline 93 & TAIWAN & $21 / 1 / 2020$ & 1 \\
\hline 94 & THAILAND & $13 / 1 / 2020$ & 1 \\
\hline 95 & TURKEY & $11 / 3 / 2020$ & 1 \\
\hline 96 & UNITED ARAB EMIRATES & $29 / 1 / 2020$ & 1 \\
\hline 97 & UZBEKISTAN & $15 / 3 / 2020$ & 1 \\
\hline 98 & VIETNAM & $22-25 / 2 / 2020$ & 16 \\
\hline 99 & NORTH KOREA & No date & $\begin{array}{l}5 \text { deaths in one day } \\
\text { raised suspicion }\end{array}$ \\
\hline \multicolumn{4}{|c|}{ EUROPEAN CONTINENT } \\
\hline 100 & ALBANIA & $8 / 3 / 2020$ & 2 \\
\hline 101 & ANDORRA & $2 / 3 / 2020$ & 1 \\
\hline 102 & AUSTRIA & $25 / 2 / 2020$ & 1 \\
\hline 103 & BELARUS & $28 / 3 / 2020$ & 1 \\
\hline 104 & BELGIUM & $4 / 2 / 2020$ & 1 \\
\hline 105 & BOSNIA AND HERZEGOVINA & $5 / 3 / 2020$ & 2 \\
\hline 106 & BULGARIA & $8 / 3 / 2020$ & 1 \\
\hline 107 & CROATIA & $25 / 2 / 2020$ & 1 \\
\hline 108 & CYPRUS & $29 / 3 / 020$ & 2 \\
\hline 109 & CZECHIA & $1 / 3 / 2020$ & 1 \\
\hline 110 & DENMARK & $27 / 2 / 2020$ & 1 \\
\hline 112 & ESTONIA & $27 / 2 / 2020$ & 1 \\
\hline 113 & FINLAND & $28 / 2 / 2020$ & 1 \\
\hline 114 & FRANCE & $24 / 1 / 2020$ & 3 first in Europe \\
\hline 115 & GEORGIA & $26 / 2 / 2020$ & 1 \\
\hline 116 & GERMANY & $27 / 1 / 2020$ & 1 \\
\hline 117 & GREECE & $26 / 2 / 2020$ & 1 \\
\hline 118 & GUERNSEY & $9 / 3 / 2020$ & 1 \\
\hline 119 & HUNGARY & $4 / 3 / 2020$ & 2 \\
\hline 120 & ICELAND & $28 / 2 / 2020$ & 1 \\
\hline 121 & IRELAND & $28 / 2 / 2020$ & 1 \\
\hline 122 & ITALY & $3 / 1 / 2020$ & 2 \\
\hline 123 & KOSOVO & $13 / 3 / 2020$ & 2 \\
\hline 124 & LATVIA & $2 / 3 / 2020$ & 1 \\
\hline 125 & LIECHTENSTEIN & $3 / 3 / 2020$ & 1 \\
\hline 126 & LITHUANIA & $28 / 2 / 2020$ & 1 \\
\hline 127 & LUXEMBOURG & $29 / 2 / 2020$ & 1 \\
\hline
\end{tabular}


Advances in Social Sciences Research Journal (ASSRJ)

Vol.7, Issue 5, Apr-2020

\begin{tabular}{|c|c|c|c|}
\hline 128 & MALTA & $7 / 3 / 2020$ & 3 \\
\hline 129 & MOLDOVA & $7 / 3 / 2020$ & 1 \\
\hline 130 & MONACO & $29 / 2 / 2020$ & 1 \\
\hline 131 & MONTENEGRO & $17 / 3 / 2020$ & 1 \\
\hline 132 & NETHERLANDS & $27 / 2 / 2020$ & 1 \\
\hline 133 & NORTH MACEDONIA & $26 / 2 / 2020$ & 1 \\
\hline 134 & NORWAY & $26 / 2 / 2020$ & 1 \\
\hline 135 & POLAND & $4 / 3 / 2020$ & 1 \\
\hline 136 & PORTUGAL & $2 / 3 / 2020$ & 2 \\
\hline 137 & ROMANIA & $26 / 2 / 2020$ & 1 \\
\hline 138 & RUSSIA & $31 / 1 / 2020$ & 2 \\
\hline 139 & SAN MARINO & $27 / 2 / 2020$ & 1 \\
\hline 140 & SERBIA & $6 / 3 / 2020$ & 1 \\
\hline 141 & SLOVAKIA & $6 / 3 / 2020$ & 1 \\
\hline 142 & SLOVENIA & $4 / 3 / 2020$ & 1 \\
\hline 143 & SPAIN & $31 / 1 / 2020$ & 1 \\
\hline 144 & SWEDEN & $31 / 1 / 2020$ & 1 \\
\hline 145 & SWITZERLAND & $25 / 2 / 2020$ & 1 \\
\hline 146 & TURKEY & $11 / 3 / 2020$ & 1 \\
\hline 147 & UKRAINE & $3 / 3 / 2020$ & 1 \\
\hline 148 & UNITED KINGDOM (UK) & $31 / 1 / 2020$ & 2 \\
\hline 149 & VATICAN CITY (HOLY SEE) & $6 / 3 / 2020$ & 1 \\
\hline \multicolumn{4}{|c|}{ NORTH AMERICAN CONTINENT } \\
\hline 150 & ANTIGUA AND BARBUDA & $10 / 3 / 2020$ & 1 \\
\hline 151 & BAHAMAS & $15 / 3 / 2020$ & 6 \\
\hline 152 & BARBADOS & $18 / 3 / 2020$ & 2 \\
\hline 153 & BELIZE & $22 / 3 / 2020$ & 1 \\
\hline 154 & CANADA & $25 / 1 / 2020$ & 1 \\
\hline 155 & COSTA RICA & $6 / 3 / 2020$ & 1 \\
\hline 156 & CUBA & $11 / 3 / 2020$ & 1 \\
\hline 157 & DENMARK & $27 / 2 / 2020$ & 1 \\
\hline 158 & DOMINICA & $22 / 2 /$ & \\
\hline 159 & DOMINICAN REPUBLIC & $1 / 3 / 2020$ & 1 \\
\hline 160 & EL SALVADOR & $18 / 3 / 2020$ & 1 \\
\hline 161 & GRENADA & $22 / 3 / 2020$ & 1 \\
\hline 162 & GUATEMALA & $13 / 3 / 2020$ & 1 \\
\hline 163 & HAITI & $19 / 3 / 2020$ & 2 \\
\hline 164 & HONDURAS & $10 / 3 / 2020$ & 2 \\
\hline 165 & JAMAICA & $10 / 3 / 2020$ & 1 \\
\hline 166 & MEXICO & $28 / 2 / 2020$ & 3 \\
\hline 167 & NICARAGUA & $19 / 3 / 2020$ & 1 \\
\hline 168 & PANAMA & $9 / 3 / 2020$ & 1 \\
\hline 169 & SAINT KITTS AND NEVIS & $11 / 3 / 2020$ & 1 \\
\hline 170 & SAINT LUCIA & $13 / 3 / 2020$ & 1 \\
\hline 171 & SAINT VINCENT AND THE GRENADINES & $11 / 3 / 2020$ & 1 \\
\hline 172 & TRINIDAD AND TOBAGO & $212 / 3 / 020$ & 1 \\
\hline 173 & UNITED STATES OF AMERICA (USA) & $20 / 1 / 2020$ & 1 \\
\hline \multicolumn{4}{|c|}{ OCEANIA CONTINENT } \\
\hline 174 & AUSTRALIA & $24 / 1 / 2020$ & 1 \\
\hline 175 & FIJI & 2020 & 1 \\
\hline 176 & KIRIBATI & 2020 & 1 \\
\hline 177 & MARSHALL ISLANDS & 2020 & 1 \\
\hline 178 & MICRONESIA & 2020 & 1 \\
\hline 179 & NAURU & 2020 & 1 \\
\hline 180 & NEW ZEALAND & 2020 & 1 \\
\hline 181 & PALAU & 2020 & 1 \\
\hline 182 & PAPUA NEW GUINEA & 2020 & 1 \\
\hline 183 & SAMOA & 2020 & 1 \\
\hline
\end{tabular}


Anero, N., \& Okankwu, E. A. (2020). Parental Educational Level as a Predictor Towards the Return Rate of Pre-Primary and Primary Pupils to School Amidst Coronavirus Pandemic in Port Harcourt Metropolis, Nigeria. Advances in Social Sciences Research Journal, 7(5) 157-172.

\begin{tabular}{|l|l|l|l|}
\hline $\mathbf{1 8 4}$ & SOLOMON ISLANDS & 2020 & 1 \\
\hline $\mathbf{1 8 5}$ & TONGA & 2020 & 1 \\
\hline $\mathbf{1 8 6}$ & TUVALU & 2020 & 1 \\
\hline $\mathbf{1 8 7}$ & VANUATU & 2020 & 1 \\
\hline $\mathbf{1 8 8}$ & AMERICAN SAMOA (USA) & 2020 & 1 \\
\hline $\mathbf{1 8 9}$ & COOK ISLANDS (NEW ZEALAND) & 2020 & 1 \\
\hline $\mathbf{1 9 0}$ & FRENCH POLYNESIA (FRANCE) & 2020 & 1 \\
\hline $\mathbf{1 9 1}$ & GUAM (USA) & 2020 & 1 \\
\hline $\mathbf{1 9 2}$ & NEW CALEDONIA (FRANCE) & 2020 & 1 \\
\hline $\mathbf{1 9 3}$ & NIUE (NEW ZEALAND) & 2020 & 1 \\
\hline $\mathbf{1 9 4}$ & NORFOLK ISLAND (AUSTRALIA) & 2020 & 1 \\
\hline $\mathbf{1 9 5}$ & NORTHERN MARIANA ISLANDS (USA) & 2020 & 1 \\
\hline $\mathbf{1 9 6}$ & PITCAIRN ISLANDS (UK) & 2020 & 1 \\
\hline $\mathbf{1 9 7}$ & TOKELAU (NEWZEALAND) & 2020 & 1 \\
\hline $\mathbf{1 9 8}$ & WAKE ISLAND (USA) & 2020 & 1 \\
\hline $\mathbf{1 9 9}$ & WALLIS AND FUTUNA (FRANCE & 2020 & 1 \\
\hline & & $7 / 3 / 2020$ & 1 \\
\hline $\mathbf{2 0 0}$ & ARGENTINA & $10 / 3 / 2020$ & 1 Confirmed at death \\
\hline $\mathbf{2 0 1}$ & BOLIVIA & $25 / 2 / 2020$ & 2 \\
\hline $\mathbf{2 0 2}$ & BRAZIL & 2020 & 1 \\
\hline $\mathbf{2 0 3}$ & CHILE & 2020 & 1 \\
\hline $\mathbf{2 0 4}$ & COLOMBIA & 2020 & 1 \\
\hline $\mathbf{2 0 5}$ & ECUADOR & 2020 & 1 \\
\hline $\mathbf{2 0 6}$ & GUYANA & 2020 & 1 \\
\hline $\mathbf{2 0 7}$ & PARAGUAY & 2020 & 1 \\
\hline $\mathbf{2 0 8}$ & PERU & 2020 & 1 \\
\hline $\mathbf{2 0 9}$ & SURINAME & 2020 & 1 \\
\hline $\mathbf{2 1 0}$ & URUGUAY & 2020 & 1 \\
\hline $\mathbf{2 1 1}$ & VENEZUELA & 2020 & 1 \\
\hline $\mathbf{2 1 2}$ & FALKLAND ISLANDS (UK) & 2020 & 1 \\
\hline $\mathbf{2 1 3}$ & FRENCH GUIANA (FRANCE) & 2020 & 1 \\
\hline $\mathbf{2 1 4}$ & SOUTH GEORGIA AND THE SOUTH & & \\
\hline & SANDWICH ISLANDS (UK) & & \\
\hline
\end{tabular}

A look at table 1 indicates that almost all the countries of the world are affected. Therefore a succeeding question will be how it got to these places. The spread to other parts of the world was through human importation, with person to person transmission through close contact, droplets from coughing and sneezing being the major known mode of transmission for now. The issue of its mode of transmission has generated some form of debate. Some people say it's a virus transmissible through the air while others say that it is the side effect of 5G network installation. It is yet to be disputed that its main source of transmission is contact with droplets from infected persons. This has threatened the public by increasing individual vulnerability but at the same time has increased human awareness on personal and environmental hygiene.

The ease of spread associated with the pandemic led to closure of schools, markets, offices and other business outlets all over the world which has hampered the world economy. No doubt, the lockdown systems will eventually resume operation and the schools will not be an exemption. It is expected that pupils will return to their business of schooling. Perhaps not all parents will want to return their children to school for fear that children may contract the disease. Besides, at present there is no known treatment for its cure and when a cure evolves, some would still wish to watch from a distance. Its incurable nature at present has prompted man to exercise caution in its extremity; so much so that the researchers ponder if parents will willingly return their children to school at resumption. It is interesting however, to know that the fears of the parents may not be for 
themselves, but for their children of pre-primary and primary school levels conforming themselves to the basic three preventive measures namely: hand washing, adequate spacing and frequent intake of fluids.

This thinking is borne out of the view that children at this level can best do anything when they are effectively supervised by their parents, caregivers and teachers. In this regard, one is justified to ask if the caregivers and teachers found in Nigerian schools can demonstrate the commitment that can be describable as effective supervision of children so as to enable children condition themselves in such a way that the schools will not be blamed peradventure the child contracts the disease. It may be surprising that the fear of returning the children when the official resumption is announced may vary on the bases of parental education. Returning or not returning children to school is predetermined by parents' veracity or rectitude. In other words parental level of education simply serves as a predictor to what would be action or position as soon as school resumes in terms of returning the children to school.

Going by this account, this study has revealed that the coronavirus (COVID-19) has no cure but measures such as frequent intake of fluid (oral sips), adequate spacing in between people, hand washing and environmental hygiene are globally adopted to mitigate the effect as well as control the spread of the disease (WHO 2019, Adnan, Suliman, Abeer, Nadia \&Rabee2019). In view of this background, parents may not completely be blamed if in their thoughts they reason that the schools whether public or private may lack the capacity to adopt the known safety measures for coronavirus and therefore choose not to return their children to schools as soon as the school resumes. This postulation attracts a research such as this to determine which of the measures would generate the phobia as would be perceived by parents that would prevent them from returning their children as the school resumes; or all the safety measures would be held accountable for the fears, parents of different educational levels, may uphold as reasons for refusing to return their children to school.

\section{PURPOSE OF THE STUDY}

The purpose of this study is to determine the rate with which parents of different educational levels will return their children on resumption of schools amidst the coronavirus pandemic, considering the capacity of the schools to adopt preventive measures in Port Harcourt Metropolis. Specifically the study intends to achieve the following objectives:

1. Determine the proportion of parents from different educational levels that will return their children due to perceived ability of the schools to carry out effective hand washing due to coronavirus pandemic in Port Harcourt Metropolis, Rivers State Nigeria.

2. Determine the proportion of parents from different educational levels that will return their children due to perceived ability of the school to observe adequate spacing of children in the schools.

3. Ascertain the proportion of parents from different educational levels that will return their children due to perceived ability of the schools to ensure that children maintain frequent intake of fluids in the form of oral sips.

4. Determine the overall proportion of parents that will return their children to school due to perceived ability of the schools to maintain preventive measures amidst coronavirus outbreak in terms of hand washing, adequate spacing and frequent intake of fluids. 
Anero, N., \& Okankwu, E. A. (2020). Parental Educational Level as a Predictor Towards the Return Rate of Pre-Primary and Primary Pupils to School Amidst Coronavirus Pandemic in Port Harcourt Metropolis, Nigeria. Advances in Social Sciences Research Journal, 7(5) 157-172.

\section{RESEARCH QUESTIONS}

Considering the purpose of this study, the following research questions are posed:

1. What proportion of parents from different educational levels will return their children due to perceived ability of the schools to carry out effective hand washing during coronavirus pandemic in Port Harcourt Metropolis, Rivers State Nigeria?

2. What proportion of parents from different educational level will return their children due to perceived ability of the school to observe adequate spacing of children in the schools?

3. What proportion of parents based on their educational levels will return their children due to perceived ability of the schools to maintain frequent intake of fluids among the children?

4. What is the overall proportion of parents that will return their children to school on resumption amidst coronavirus outbreak?

\section{DEFINITION OF TERMS}

In this study the following terms are understood as follows:

1. Hand washing: Washing of hands in this study refers to the ability of the schools to organize the children to wash their hands within close intervals using soap and other detergents under a running water like a tap and which the washing exercise can last for not less than 20 seconds each time the child washes hand.

2. Adequate spacing: This simply refers to a situation where the teachers, children and visitors must be two meters away from each other while in the classrooms, playgrounds, offices or where ever they find themselves.

3. Frequent intake of fluids: This is used to refer to the ability of the schools to prompt the children to frequently take water such that the liquid can wash whatever, from the throat to the stomach where hydrochloric acid will burn it off. The liquid substance can be water, nonalcoholic drinks, soup, pepper soup but none of the substances should be poisonous.

\section{RESEARCH METHODOLOGY}

476,658 (four hundred and seventy six thousand, six hundred and fifty eight) adults otherwise parents constituted the study's population (National Population Commission of Nigeria, 2017). Out of the study population, the researchers sampled as much as 942 (nine hundred and forty two parents. The parents were deemed as the most appropriate subjects because they are in the position to decide whether or not to return their children to school. To sample the 942 parents, for the study, accidental sampling technique was adopted. The accidental sampling technique was considered suitable for the study because the sampled parents were not found in one place and not all of them were willing to volunteer information as it has to do with return of their children on resumption of schools amidst coronavirus pandemic. Besides, the Researchers took a little time to verbally explain the content of the questionnaire to some of the parents and solicited for the parents' responses.

\section{INSTRUMENTATION}

The main instrument for the study was a YES or NO response questionnaire. Addition to this, was an oral interaction the Researchers had with the respondents. The instrument was designed to determine the perception of parents as regards the ability of the schools to implement coronavirus control measures. The measures are if the schools can observe children carry out effective hand washing, maintain adequate spacing among the children and ensure frequent fluid intake by the children. 
The questionnaire items were subjected to validation by presenting it to a Health expert in Cottage Hospital Obio Rivers State and an Educational Test and Measurement expert in Ignatius Ajuru University of Education, Port Harcourt. Considering their inputs, some corrections were made and the instrument was deemed valid for the study. Since the main target of the study was to determine the rate with which parents of different educational levels will return their children on resumption of schools amidst the coronavirus pandemic, the questionnaire was made up of three (3) items to address the three known measures for preventing coronavirus. A sample of the questionnaire is as shown in table 2.

Table 2 (QUESTIONNAIRE): Return of Children to School by Parents amidst Coronavirus Pandemic INSTRUCTION: Please tick $(\sqrt{ })$ or indicate as may be applicable to you.

\begin{tabular}{|c|c|c|c|c|c|c|c|c|}
\hline \multicolumn{9}{|c|}{ EDUCATIONAL LEVELS } \\
\hline \multicolumn{2}{|c|}{\begin{tabular}{|l|} 
Incomplete \\
Primary Education
\end{tabular}} & FSLC & WASC & OND/NCE & $\begin{array}{l}\text { B.A, } \\
\text { B.Sc } \\
\text { B,Ed }\end{array}$ & $\begin{array}{l}\text { M.A } \\
\text { M.Sc } \\
\text { M.Ed }\end{array}$ & \multicolumn{2}{|l|}{ Ph.D } \\
\hline S/N & \multicolumn{6}{|c|}{ ITEMS } & YES & NO \\
\hline 1 & \multicolumn{6}{|c|}{$\begin{array}{l}\text { I will support the return of children to school on resumption amidst } \\
\text { coronavirus outbreak since the schools can observe children carry out effective hand } \\
\text { washing as a preventive measure. }\end{array}$} & & \\
\hline 2 & \multicolumn{6}{|c|}{$\begin{array}{l}\text { I will support the return of children to school on resumption amidst } \\
\text { coronavirus outbreak since the schools can maintain adequate spacing in between } \\
\text { children as a preventive measure. }\end{array}$} & & \\
\hline 3 & \multicolumn{6}{|c|}{$\begin{array}{l}\text { I will support the return of children to school on resumption amidst } \\
\text { coronavirus outbreak due to the ability of the schools to maintain } \\
\text { frequent fluid intake by the children as a preventive measure. }\end{array}$} & & \\
\hline
\end{tabular}

\section{ADMINISTRATION OF INSTRUMENT}

To effectively reach the parents, the Researchers stumbled into parents in public places such as markets, churches, mosques, shopping malls, filing stations, motor parks; and some were reached in their houses and streets. It is important to indicate that not all the parents that were approached accepted to respond to the questionnaire. However, 947 (nine hundred and forty seven) parents were sampled out of which 942 number was used for the analysis. The 5 (five) unused questionnaire which is about $0.53 \%$ of the total number of questionnaire sampled. The percentage that was not used for analysis was due to error in filling the questionnaire and inability of some parents to return the questionnaire items to the researchers before the analysis was done. The data generated was analyzed using simple percentage.

\section{DATA ANALYSIS, RESULTS AND DISCUSSION}

The results of the data analysis are presented using tables 3 to 6 . Each table presents the data, result and interpretation of each research question. Immediately after each interpretation comes the discussion of finding. A total of 4 research questions are hereby analyzed and discussed.

Research question 1: What proportion of parents from different educational level will return their children due to perceived ability of the school to observe frequent hand washing in the schools? 
Anero, N., \& Okankwu, E. A. (2020). Parental Educational Level as a Predictor Towards the Return Rate of Pre-Primary and Primary Pupils to School Amidst Coronavirus Pandemic in Port Harcourt Metropolis, Nigeria. Advances in Social Sciences Research Journal, 7(5) $157-172$.

Table 3: Summary of percentage responses on the proportion of parents from different educational levels that will return their children due to perceived ability of the school to observe effective hand washing by children in the schools

\begin{tabular}{|l|l|l|l|l|l|}
\hline Qualification & $\begin{array}{l}\text { No. of YES } \\
\text { Response }\end{array}$ & $\begin{array}{l}\text { \% of YES } \\
\text { Response }\end{array}$ & $\begin{array}{l}\text { No. of NO } \\
\text { Response }\end{array}$ & $\begin{array}{l}\% \text { of NO } \\
\text { Response }\end{array}$ & $\begin{array}{l}\text { Total Number } \\
\text { of Respondents }\end{array}$ \\
\hline $\begin{array}{l}\text { Incomplete Primary } \\
\text { Education(IPE) }\end{array}$ & 20 & 28.57 & 50 & 71.43 & 70 \\
\hline FSLC & 50 & 44.64 & 62 & 55.36 & 112 \\
\hline WASC & 80 & 36.04 & 142 & 63.96 & 222 \\
\hline Diploma/NCE & 88 & 56.41 & 68 & 43.59 & 156 \\
\hline B.A, B.Sc, B. Ed & 136 & 56.20 & 106 & 43.80 & 242 \\
\hline M. Ed, MA, M.Sc & 86 & 78.18 & 24 & 21.82 & 110 \\
\hline Ph.D & 26 & 86.67 & 4 & 13.33 & 30 \\
\hline Total & 486 & 51.59 & 456 & 48.41 & 942 \\
\hline
\end{tabular}

The result on Table 3 shows the summary of percentage responses on the proportion of parents from different educational levels that will return their children due to perceived ability of the school to observe effective hand washing by children in the schools. Specifically, $86.67 \%$ of the parents with $\mathrm{PhD}, 78.18 \%$ of parents with master's degree, $56.41 \%$ of parents who had Diploma/NCE and then $56.20 \%$ of parents with bachelor degree among others will return their children due to perceived ability of the school to observe effective hand washing by children in the schools.

The first finding of this study established that parents whose educational qualifications range from diploma to terminal degrees predict that schools can easily organize hand washing for children while those unable to complete primary school or possess First School Leaving Certificate and those with West African School Certificate as educational certificates doubt the capacity of the schools to administer regular hand washing among school children. This finding can be interpreted to mean that those with higher educational levels understand that hand washing is a simple procedure that can be practiced by anyone. The finding therefore suggests that those with lower educational certificates do not perceive it as a simple exercise. The different views of the parents with low and high educational certificate notwithstanding, the Citizens Information Centre (2019) contends that it is the teachers 'responsibility to protect children from incurring any form of injury or harm while they are in the schools.

This position of the Citizens Information Centre suffices to say that the school which is the teacher personified has to adopt all available strategies to keep the child safe from contracting any disease or harm. In this regard, WHO (2020) among other measures recommends that regular hand having is one of the preventive strategies for anyone to avert contract of COVID19. Naturally, one expects the school or teachers who are the custodian of the children to do their bit to conform to the health practices for the safety of the children during and after the reign of COVID19.Justifying why the business of hand wash and other hygiene measures must be taken serious by teachers and schools Joshi and Amadi (2013) has it that the provision and use of hand sanitizers in preschool and primary schools have among other things reduced the rate of disease transmission among children. 
The agitation raised by those with lower level of education that the schools cannot effectively conduct effective hand wash among children may not completely be wished away. This is because some schools may still be operating in obscure and unacceptable places. This reminds any one that if education is conceived as a strong index for determining social stratification, one may see reasons why the finding of this study reveals that those with the lowest level of education may be found in the low social economic class who may send their children to schools that may not be equipped with basic facilities such as tap water, good toilet system, play grounds among others. Considerably, the idea of organizing regular hand wash for children who attend such schools may be a mirage.

Research question 2: What proportion of parents from different educational level will return their children due to perceived ability of the school to observe adequate spacing of children in the schools?

Table 4: Summary of percentage responses on the proportion of parents from different educational levels that will return their children due to perceived ability of the school to observe adequate spacing of children in the schools

\begin{tabular}{|l|l|l|l|l|l|}
\hline Qualification & $\begin{array}{l}\text { No. of YES } \\
\text { Response }\end{array}$ & $\begin{array}{l}\text { \% of YES } \\
\text { Response }\end{array}$ & $\begin{array}{l}\text { No. of NO } \\
\text { Response }\end{array}$ & $\begin{array}{l}\text { \% of NO } \\
\text { Response }\end{array}$ & $\begin{array}{l}\text { Total Number of } \\
\text { Respondents }\end{array}$ \\
\hline $\begin{array}{l}\text { Incomplete Primary } \\
\text { Education(IPE) }\end{array}$ & 14 & 20.00 & 56 & 80.00 & 70 \\
\hline FSLC & 36 & 32.14 & 76 & 67.86 & 112 \\
\hline WASC & 54 & 24.32 & 168 & 75.68 & 222 \\
\hline Diploma/NCE & 26 & 16.67 & 130 & 83.33 & 156 \\
\hline B.A, B.Sc, B. Ed & 56 & 23.14 & 186 & 76.86 & 242 \\
\hline M. Ed, MA, M.Sc & 38 & 34.55 & 72 & 65.45 & 110 \\
\hline Ph.D & 10 & 33.33 & 20 & 66.67 & 30 \\
\hline Total & $\mathbf{2 3 4}$ & 24.84 & $\mathbf{7 0 8}$ & 75.16 & $\mathbf{9 4 2}$ \\
\hline
\end{tabular}

The result on Table 4 shows the summary of percentage responses on the proportion of parents from different educational levels that will return their children due to perceived ability of the school to observe adequate spacing of children in the schools. Specifically, 34.55\% of parents with master's degree, $33.33 \%$ of parents with PhD, $32.14 \%$ of parents with FSLC and $23.14 \%$ of the parents with bachelor degree will return their children among others will return their children due to perceived ability of the school to observe adequate spacing of children in the schools.

The second major finding of this study shows that all category of parents irrespective of educational levels will not return their children to school, if government announces a resumption date for the schools by the end or close to the end of coronavirus pandemic; due to the fact that they predict that schools cannot observe adequate spacing in between children in the schools as prescribed measure for averting the transmission of the virus. In this study, adequate spacing is used to mean a situation where the teachers, children and visitors must be two meters away from each other while in the classrooms, playgrounds, offices or where ever they find themselves. Going by the position of all category of parents, children will not return to school as soon as the government announces the resumption date. The fears upheld by parents as established in this study is justifiable because children are generally observed to be difficult to control hence they wish to remain in constant 
Anero, N., \& Okankwu, E. A. (2020). Parental Educational Level as a Predictor Towards the Return Rate of Pre-Primary and Primary Pupils to School Amidst Coronavirus Pandemic in Port Harcourt Metropolis, Nigeria. Advances in Social Sciences Research Journal, 7(5) 157-172.

contact with their peers. Besides, the pre-primary and primary schools are known for chiefly adopting paly as its major pedagogical approach for teaching children. Considerably, the teachers and minders may not suddenly change their approach of instruction assuming the schools may have available space to maintain the two meter physical distancing as constantly jingled in state and national radio and television stations.

Commenting on children and play, Guciritz (2016) asserted that from the age of three, children socializes more and begin to enjoy social relationship with peers as never before; consequently mix up more freely during plays. The uncontrolled nature of children resulting from play makes it difficult to guarantee the two meter distancing from one another in schools.

Before delving into more detailed discussion on distancing in schools, it will be proper to exhaust discussion on the child and play. It is important to recall that speaking on the child and play, the International Play Association (2012) referencing the United Nations (UN) position of the child and play observed that the UN contends that play is a fundamental right of the child. The position of the UN means that obstruction of the child from play for whatever reason whether COVID19 or whatever counters or breaches the right of the child. The stand of UN gives credence to the position of all category of parents that the schools cannot maintain physical distancing among children as a result, decline the return of their children if government announces a resumption date for the schools by the end or close to the end of coronavirus pandemic.

The uncontrolled movements made by children in course of their play is one thing and the spaces available in the schools that can enable the schools maintain the recommended distancing of persons in schools is another which naturally should attract debate. The nature of classrooms in Nigerian schools has always been described as overcrowded or large, so how can such level of distance be maintained. In this connection, Asodike and Onyeike (2016) identified the features of a large class to among other things include a small space but over-flown with many pupils and the children have a feeling of been over crowded. By the declaration made by Asodike and Onyeike one doubts if the nature of Nigerian classrooms and its environment can warrant a two meter distancing of persons. The parents whose children are direct victims of the crowded nature of the classes are acquainted with the impossibilities surrounding the maintenance of two meter distancing among persons found in any school community and this may be accountable for the unanimous declaration made by all parents that schools cannot maintain a two meter distance among members of the school community.

Research question 3: What proportion of parents from different educational levels will return their children due to perceived ability of the school to maintain frequent intake of fluids among children? 
Table 5: Summary of percentage responses on the proportion of parents from different educational levels that will return their children due to perceived ability of the school to administer frequent intake of fluids among pupils?

\begin{tabular}{|l|l|l|l|l|l|}
\hline Qualification & $\begin{array}{l}\text { No. of YES } \\
\text { Response }\end{array}$ & $\begin{array}{l}\text { \% of YES } \\
\text { Response }\end{array}$ & $\begin{array}{l}\text { No. of NO } \\
\text { Response }\end{array}$ & $\begin{array}{l}\text { \% of NO } \\
\text { Response }\end{array}$ & $\begin{array}{l}\text { Total Number } \\
\text { of Respondents }\end{array}$ \\
\hline $\begin{array}{l}\text { Incomplete Primary } \\
\text { Education(IPE) }\end{array}$ & 16 & 22.86 & 54 & 77.14 & 70 \\
\hline FSLC & 12 & 10.71 & 100 & 89.29 & 112 \\
\hline WASC & 40 & 18.02 & 182 & 81.98 & 222 \\
\hline Diploma/NCE & 24 & 15.38 & 132 & 84.62 & 156 \\
\hline B.A, B.Sc, B. Ed & 48 & 19.83 & 194 & 80.17 & 242 \\
\hline M. Ed, MA, M.Sc & 32 & 29.09 & 78 & 70.91 & 110 \\
\hline Ph.D & 12 & 40.00 & 18 & 60.00 & 30 \\
\hline Total & $\mathbf{1 8 4}$ & $\mathbf{1 9 . 5 3}$ & $\mathbf{7 5 8}$ & $\mathbf{8 0 . 4 7}$ & $\mathbf{9 4 2}$ \\
\hline
\end{tabular}

The result on Table 5 shows the summary of percentage responses on the proportion of parents from different educational levels that will return their children due to perceived ability of the school to carry out effective administration of frequent intake of fluidsamong pupils in Port Harcourt Metropolis, Rivers State Nigeria. Specifically, 40.00\% of the parents with PhD, $29.09 \%$ of the parents with bachelor degree will return their children; this was followed by $19.83 \%$ of the parents who had master's degree and then $18.02 \%$ of those with WASC among others.

The result of this study with respect to fluids administration to children by schools on resumption by the end or close to the end of coronavirus pandemic indicates that all parents, irrespective of educational background upheld the perception that schools do not possess the ability to administer fluids to children as a preventive measure to the infection of coronavirus. This finding states that all parents going by their educational grouping strongly opposed the view that schools can administer fluids to pupils. Pondering on why a significant proportion of parents did not consent to the idea that schools can afford sufficient fluids attracts a question of determining what fluid is. In this study, fluid is conceptualized as liquid substances which can be water, non-alcoholic drinks, soup, pepper soup but none of the substances should be poisonous. It is important to add that whatever is considered as fluid must be taken at close intervals.It can be admitted that it is impossible for schools to cook or prepare any substance outside water and give to children without the approval of the parents. As an African culture the fear that the child is not expected to eat anything without the knowledge of the parents is a common practice among Nigerians.This element of the African culture may be attributed to the refusal of all category of parents that the schools cannot administer fluids as a preventive measure to coronavirus. Although water is generally accepted and given to both old and young yet the parents were of the view that fluid administration to children is not an assignment the schools can credibly execute. Prying into the rationale behind the position of parents, UNICEF (2018) reports that in Nigeria, 69 million people do not have access to portable water. The report also has it that children spend a huge chunk of time each day sourcing for water and in the process miss classes. The response of the parents seems to be affirm the position of parents.The parents' opinion may be traced to the fact that the schools may not have a dependable source of portable water supply. 
Anero, N., \& Okankwu, E. A. (2020). Parental Educational Level as a Predictor Towards the Return Rate of Pre-Primary and Primary Pupils to School Amidst Coronavirus Pandemic in Port Harcourt Metropolis, Nigeria. Advances in Social Sciences Research Journal, 7(5) 157-172.

Availability of water in schools brings to mind the ability of teachers and care givers to take the measure of discipline required to remind children to take water at close intervals. This point should not be over looked because the teachers and care givers in Nigerian schools are known for been grossly saddled with the day-to-day classroom activities; so additional responsibility may be a mirage. Another issue is whether the water carried by the children to school will be enough as would be required by the child throughout the period of stay in the school. Where it may not be sufficient, do the schools have the capacity to provide portable water for the children? The sincere answer to this question is no. Considering the fears expressed in this paragraph, one can infer that parents are afraid of the children contracting another infection from water source in the bid to curb coronavirus infection as most schools will not be able to provide a good source of portable water supply. This is as highlighted by Nwabor, Nnamonu, Martins and Ani (2016) who contend that waterborne infections remain a public health concern as investment on its research has not yielded expected results and majority of world population use unimproved water sources. In the same vein, it is important to observe that the reports of Chard, Trinies, Moss, Chang, Doumbia, Lammie and Freeman (2018) and Planet Aid's (2016) can be summed to say that there is reduction in enteric diseases among pupils in schools with good water, sanitation and hygiene; in schools where there is unsafe water, children are known to suffer diseases like diarrhea and related water borne diseases. Considering how though it has been for schools to provide a liquid as simple as water and its effects on children, no one may agitate against the positionof parentsthat schools cannot cope with the business of administering frequent intake of fluid by children as a preventive measure to COVID19.

Research question 4: What is the overall proportion of parents that will return their children on school resumption amidst coronavirus outbreak in terms of hand washing, adequate spacing and intake of fluid?

Table 6: Summary of percentage responses on the overall proportion of parents that will return their children on school resumption amidst coronavirus outbreak in terms of washing hand, adequate spacing and intake of fluids

\begin{tabular}{|l|l|l|l|l|l|}
\hline Variables & $\begin{array}{l}\text { Total number } \\
\text { of Respondents }\end{array}$ & $\begin{array}{l}\text { No. of YES } \\
\text { Response }\end{array}$ & $\begin{array}{l}\text { \% of YES } \\
\text { Response }\end{array}$ & $\begin{array}{l}\text { No. of no } \\
\text { Response }\end{array}$ & \% of no Response \\
\hline Hand washing & 942 & 486 & $51.59 \%$ & 456 & $48.41 \%$ \\
\hline Adequate spacing & 942 & 234 & $24.84 \%$ & 708 & $75.16 \%$ \\
\hline Intake of fluid & 942 & 184 & $19.53 \%$ & 758 & $80.47 \%$ \\
\hline
\end{tabular}

The result on Table 6 shows the summary of percentage responses on the overall proportion of parents that will return their children on school resumption amidst coronavirus outbreak in terms of hand washing, adequate spacing and administering fluids. It shows that $19.53 \%$ of the parents will return their children due to perceived ability of the school to frequently administer fluids, $24.84 \%$ favoured adequate spacing of children whereas $51.59 \%$ will return their children due to perceived ability of the school to observe effective hand washing of children in the schools. 
The last result of this study indicates that parents generally has no hope in the schools implementing the coronavirus preventive measures apart from the view that schools can carry out hand washing as a preventive measure. The essence of considering parental view holistically is to find out which of the measures is admissible by the schools. The finding may not be rejected because water meant for washing hand may not be used for drinking hence drinking water must be pure such that it does not contain impurities or diseases. In the case of washing hand, the water running from tap which may not necessarily be deemed pure can be used. It is not subject to argument that most tap water in our schools and homes cannot not be certified safe for drinking but they are generally used for hand wash. Commenting on this, Centre for Disease, Control and Prevention (2018) has it that hands should be washed with soap and clean running water for at least 20 seconds. This concept of washing hand in a running water may have informed parents that assume that schools with tap water meets the hand wash requirement.

\section{CONCLUSION}

The outbreak of COVID19 and its effects on man and his activities is no news to any one on the planet earth. Some sectors of the society are still operating but with strict adherence to the prevention measures. One of such sectors is the bank. The outbreak led to sudden closure of the schools and other public places. The lock down by human imagination may not be forever. Peradventure, the pandemic is over or last longer than human patience, some parents may be tempted to return their children to school but not without some underlined fears. Some such worries may suffice in two ways: when will the pandemic be completely eliminated and are the prevention strategies admissible by schools? The views that may be upheld by parents in responding to these agitations can be predicted based on their educational background. This view cannot completely be ignored because the views of parents whose educational background range from Diploma certificate to the terminal degrees agree that schools cannot guarantee effective implementation of hand wash as a precautionary measures to the spread of COVID19 but they all agreed that the schools cannot effectively ensure adequate spacing and fluid intake. However, the parents proportionally speaking agree that the schools can comply with the idea of regular washing of hands. The finding of this study therefore imposes fear that most parents may be reluctant to return their children to school. Besides, the day care and primary school learning activities or pedagogical approaches demands close interactions among teachers and pupils. For these reasons, the schools can only be in full operation when there is a known cure for the virus where complete elimination of the virus among humans is not possible.

\section{RECOMMENDATIONS}

1. Since some category of parents agree that the schools cannot enforce hand wash by children, NGO'S and public spirited individuals need to enlighten the schools on the need to take the business of hand wash serious.

2. Since the study established that the schools cannot maintain adequate spacing as a preventive measure to COVID19, the government or its supervisory agencies must urge the schools to operate two to three shift system so as to have adequate space and facilities that would enable them maintain the recommended social or physical distancing.

3. The parents agree that the schools cannot administer fluids to the children, the government must ensure that any school that will operate must have a source of portable water confirmed by National Agency for Food and Drug Administration and Control (NAFDAC) 
Anero, N., \& Okankwu, E. A. (2020). Parental Educational Level as a Predictor Towards the Return Rate of Pre-Primary and Primary Pupils to School Amidst Coronavirus Pandemic in Port Harcourt Metropolis, Nigeria. Advances in Social Sciences Research Journal, 7(5) $157-172$.

\section{References}

Adnan S, Suliman K, Abeer K, Nadia B and Rabee S ( 2019) COVID-19 infection: Origin,transmission and characteristics of human coronaviruses . Retrieved on 5/4/20 from

Asodike, J. D. and Onyeike, V. C. (2016). Managing large classes in developing countries. Global Journal of Educational Research. 15(1), 31-39

Chard, A. N., Trinies, V., Moss, D., Chang, H., Doumbia, S., Lammie, P. and Freeman, C. (2018).The impact of school water, sanitation and hygiene improvements on infectious diseases using serum antibody detection. Retrieved from https://journals.plos.org/plosntds/article $=10.1371 /$ journal on 22nd April, 2020

Centre for Disease, Control and Prevention (2018). Hand washing, hygiene and diapering. Retrieved from https://www.cdc.gov/healthywater/emergency/hygiene-handwashing-diapering/index.html on 26th April, 2020

\section{Bottom of Form}

Citizens Information Centre (2019) Teachers' duty of care. Retrieved 20/4/2020 from

https://www.citizensinformation.ie/en/education/primary_and_post_primary_education/teachers_and_schools/teac hers_duty_of_care.html

ECOWAS (2020) ECOWAS measures to prevent and control the spread of Corona virus disease COVID-19.retrieved 5/4/20 from https://www.ecowas.int/up-content/uploads/2020/03/ECOWAS-statement-on-corona-virus-disease2019.

Guciritz L (2016) types of play important you're your child's development. Retrieved 21/4/2020 from https://www.healthline.com/health/parenting/types-of-play

International Play Association (2012) UN Convention on the Rights of the Child. Retrieved 22/4/20 from https://www.ipaworld.com.

Joshi A and Amadi C (2013). Impact of Water, Sanitation, and Hygiene Interventions on Improving Health Outcomes among School Children. Retrieved 22/4/20 https://www.hindawi.com/journals/jeph

National Population Commission of Nigeria (2017). The population development in Rivers as well as related information and services. Retrieved 10/4/2020 from

https://www.citypopulation.de/php/nigeria-admin.php?adm1id.

Nwabor, O. F.,Nnamonu, E., Martins, P., and Ani, C. (2016). Water and waterborne diseases: A review. Retrieved from https://www.researchgate.net/publication/water_and_waterborne_diseaes_a_review on 22nd April, 2020

Planet Aid's (2016). Getting kids in school: The problem of water and sanitation. Retrieved from https://www.planetaid.org/org/blog/getting-kids-in-school-the problem-of-water-and-sanitation on 22nd April, 2020

UNICEF (2018). Easy access to water promotes school attendance in Nigeria. Retrieved from https://www.unicef.org/wca/stories/easy-access-water-promotes-school-attendance-Nigeria on 26th April, 2020

World Health Organization (2019). Basic protective measures against the new coronavirus. Retrieve 5/4/20 from https://www.who.int/emergencies/diseases/novel-coronavirus-2019/advice-for-public 